\title{
KLASTROWY PRODUKT TURYSTYCZNY JAKO WYZWANIE STRATEGICZNE W ZARZĄDZANIU KLASTREM TURYSTYCZNYM
}

\begin{abstract}
Artykuł koncentruje się na problematyce klastrowego produktu turystycznego, postrzeganego współcześnie jako wyzwanie strategiczne w zarządzaniu klastrem turystycznym w Polsce. W dwóch jego częściach w sposób syntetyczny przedstawiono zakres aktywności klastrów turystycznych, a także istotę i znaczenie klastrowego produktu turystycznego. W oparciu o wyniki analizy literatury przedmiotu i danych zastanych wykazano, że klastry turystyczne można traktować jako element procesów rozwojowych w gospodarce na poziomie makro, mezo i mikro. Ich aktywność pozwala bowiem z jednej strony na zaspokajanie różnorodnych potrzeb i oczekiwań turystów, a z drugiej na wzmacnianie konkurencyjności gospodarki. Stwarzają one dogodne warunki dla mikro, małych i średnich podmiotów gospodarki turystycznej, których dotychczasowy potencjał strategiczny był mało konkurencyjny. Pozwalają przezwyciężać słabości polskiej turystyki, związane z jakością usług turystycznych, bazą noclegową, rozproszoną ofertą turystyczną, czy ze stopniem wykorzystania potencjału sektora turystyki. Ponadto sprzyjają rozwojowi zrównoważonej gospodarki opartej na wiedzy oraz zapewnieniu spójności gospodarczej, społecznej i terytorialnej, reprezentując specyficzną formę partnerstwa terytorialnego, regionalnej i sektorowej współpracy, a niekiedy nawet międzyregionalnej i międzysektorowej.

Jednocześnie w artykule podkreślono, że rozwój klastrów turystycznych wymaga sprawnego zarządzania i wymiernego wsparcia kluczowych interesariuszy m.in. władz publicznych i inwestorów. Aby mogły dostarczać optymalne korzyści (wartość dodaną) dla swych interesariuszy wewnętrznych i zewnętrznych na danym terytorium ich zakorzenienia niezbędne jest wpierw opracowanie odpowiednio zintegrowanego klastrowego produktu turystycznego, a następnie elastyczne oferowanie go klientom (turystom). Współpraca w tym obszarze koordynatora i członków klastra, m.in. lokalnego biznesu, podmiotów sektora $\mathrm{B}+\mathrm{R}$ i instytucji otoczenia biznesu, zwiększa szansę na pomyślność tego przedsięwzięcia. Fundamentem klastrowego produktu turystycznego jest bowiem połączenie jego jakości i innowacyjności ze specyficznymi cechami regionu zakorzenienia klastra, w tym walorami przyrodniczymi oraz wielowymiarowym dziedzictwem kulturowo-historycznym.
\end{abstract}

Słowa kluczowe: klaster, zarządzanie, turystyka, marketing, produkt, rozwój.

\section{WPROWADZENIE}

Klastry turystyczne w Polsce już od wielu lat są przedmiotem zainteresowania przedstawicieli różnych środowisk m.in. polityki, biznesu i nauki, głównie z uwagi na ich strategiczne znaczenie dla długofalowego procesu przemian dokonujących się w gospodarce

\footnotetext{
${ }^{1}$ Dr Bogusław Bembenek, Katedra Przedsiębiorczości, Zarządzania i Ekoinnowacyjności, Wydział Zarządzania, Politechnika Rzeszowska im. Ignacego Łukasiewicza, Al. Powstańców Warszawy 8, 35-959 Rzeszów; e-mail: bogdanb@prz.edu.pl.
} 
turystycznej. Jako organizacje mniej lub bardziej sformalizowane, współtworzone przede wszystkim przez współpracujące i konkurujące ze sobą podmioty gospodarki turystycznej, funkcjonują w przestrzeni geograficznej o określonym poziomie dostępności walorów turystycznych, infrastruktury turystycznej i paraturystycznej. Ich koordynatorzy, dążąc do zapewnienia im korzystnych warunków dla rozwoju i efektywnego wykorzystania posiadanych zasobów, niejednokrotnie muszą zmierzyć się z wyzwaniem, jakim jest stworzenie i komercjalizacja klastrowego produktu turystycznego, odpowiednio atrakcyjnego, oryginalnego i zapewniającego wartość dodaną dla różnych grup interesariuszy (np. członków klastra, turystów, władz samorządowych). Aby skutecznie sprostać temu wyzwaniu strategicznemu, wymagane jest zaangażowanie zarówno samego koordynatora, jak i członków klastra. Jakość ich współpracy w obszarze opracowania i oferowania klientom mniej lub bardziej zintegrowanego produktu turystycznego wyznacza dynamikę rozwoju klastrowego łańcucha wartości.

Celem artykułu koncepcyjnego jest charakterystyka roli i znaczenia klastrowego produktu turystycznego $\mathrm{w}$ procesie zarządzania rozwojem klastra turystycznego w Polsce. $\mathrm{W}$ ramach tak określonego celu poszukiwano odpowiedzi na cztery pytania badawcze:

- co stanowi istotę klastra turystycznego i klastrowego produktu turystycznego?

- jakie endo- i egzogeniczne uwarunkowania mają decydujące znaczenie w rozwoju klastrów turystycznych?

- dlaczego zintegrowany klastrowy produkt turystyczny stanowi strategiczne wyzwanie w zarządzaniu rozwojem klastra turystycznego?

- jakie potencjalne korzyści zapewnia klastrowy produkt turystyczny?

Proces badawczy, podporządkowany realizacji celu artykułu, opierał się głównie na analizie literatury przedmiotu i danych zastanych (desk research). Należy przy tym podkreślić, że wybór problematyki badawczej uwzględnia zainteresowania naukowe autora artykułu, dotyczące przedsiębiorczego zarządzania klastrem. Ponadto wynika on z faktu, że w warunkach dyskusji o kształcie polityki klastrowej szczególnego znaczenia nabiera jakość zarządzania klastrami. Pośród wielu publikacji naukowych z zakresu klasteringu turystycznego, wciąż relatywnie niewiele jest tych, które koncentrują się na klastrowym produkcie turystycznym, w różnym stopniu zintegrowanym. Przedstawione rozważania mogą zatem przyczynić się do uzupełnienia istniejącej w tym obszarze luki wiedzy i stanowić źródło inspiracji w projektowaniu dalszych badań jakościowych i ilościowych.

\section{AKTYWNOŚĆ KLASTRÓW TURYSTYCZNYCH - PRÓBA SYNTEZY}

Klastry powstają w różnych sferach aktywności społecznej i gospodarczej, w sektorach zarówno zaawansowanych technologicznie, jak i tradycyjnych. W literaturze przedmiotu wielokrotnie podkreśla się, że turystyka jako strategiczna dziedzina gospodarki, związana z miejscowościami turystycznymi, lokalną konsumpcją i ruchem turystycznym, stanowi doskonały obszar dla rozwoju klastrów. W tym przypadku koncepcja klasteringu jest szczególnie użyteczna dla regionów turystycznych, które poszukują różnych możliwości wzmacniania swojej konkurencyjności w stosunku do istniejących ofert turystycznych na rynku krajowym i zagranicznym, coraz bardziej globalnym² ${ }^{2}$

\footnotetext{
${ }^{2}$ B. Klemens, N. Derlukiewicz, Rola struktur klastrowych $w$ rozwoju miast $w$ perspektywie 2020
} (aspekt turystyczny), ,Studia Miejskie” 2014, t. 16, s. 22. 
Według A. Kołodziejczak klastry i inicjatywy klastrowe są ważnym instrumentem aktywizacji społeczno-gospodarczej regionów, a także wspólnej ochrony walorów przyrodniczych i kulturowych oraz wykorzystania ich na potrzeby rozwoju funkcji turystycznej danego regionu i partnerstwa turystycznego ${ }^{3}$. W programie rozwoju turystyki do 2020 roku w Polsce przyjęto, że wzmocnienie rozwoju konkurencyjnej i innowacyjnej turystyki z poszanowaniem zasad zrównoważonego rozwoju możliwe będzie m.in. dzięki sieciom klastrowym w turystyce. Tym bardziej zasadne jest publiczne wspieranie klasteringu turystycznego w poszczególnych regionach kraju4

Pojęcie klastra turystycznego określane jest bardzo szeroko, gdyż związane jest ono $\mathrm{z}$ istotą turystyki, atrakcyjnością turystyczną, produktem turystycznym, partnerstwem terytorialnym czy turystycznym łańcuchem wartości. Na gruncie nauk o zarządzaniu pojęcie to definiowane jest dla przykładu jako ${ }^{5}$ :

- aktywna i dynamiczna sieć strategiczna wytwórców produktów turystycznych, współpracujących i konkurujących ze sobą jakością i unikatowością w ramach określonej przestrzeni geograficznej,

- grupa firm i instytucji wzajemnie powiązanych relacjami pionowymi, poziomymi i diagonalnymi w ich łańcuchu wartości poprzez wspólny produkt lub kilka produktów turystycznych na danym obszarze,

- geograficzne skupisko powiązanych ze sobą przedsiębiorstw świadczących usługi turystyczne i wytwarzających produkty turystyczne oraz ich dostawców, klientów, partnerów z sektora $\mathrm{B}+\mathrm{R}$, instytucji otoczenia biznesu, związanych z sektorem turystyki i sektorami pokrewnymi,

- forma zrzeszania grup społecznych, a także różnorodnych organizacji komercyjnych, społecznych i publicznych, działających na danym terytorium w obszarze turystyki i związanych z nią innych form aktywności gospodarczej,

- skoncentrowany na danym obszarze łańcuch wartości podmiotów z sektora turystyki i sektorów powiązanych, wspólnie działających na rzecz atrakcyjności turystycznej swego terytorium,

- sieć strategiczna podmiotów tzw. bezpośredniej i pośredniej gospodarki turystycznej (stricte turystycznych i paraturystycznych), zaangażowanych w rozwój regionu turystycznego poprzez sprawne wykorzystanie posiadanych zasobów i zapewnienie szerokiego wachlarza atrakcji, udogodnień i infrastruktury, adekwatnych do potrzeb krajowych i zagranicznych turystów.

\footnotetext{
${ }^{3}$ A. Kołodziejczak, Inicjatywy klastrowe jako narzędzie regionalnego rozwoju turystyki, „Studia Komitetu Przestrzennego Zagospodarowania Kraju Polskiej Akademii Nauk” 2016, t. CLXXII, s. 147.

${ }^{4}$ Uchwała nr 143/2015 Rady Ministrów z dnia 18 sierpnia 2015r. w sprawie przyjęcia „Programu Rozwoju Turystyki do 2020 roku", s. 36-39.

5 E. Skowronek, Klaster jako forma wspótpracy w turystyce, „Europa Regionum” 2015, t. XXIV, s. 131; K. Sala, Clusters as a form of cooperation and innovation on the example of the Bieszczady Cross-Border Tourism Cluster, ,The Malopolska School of Economics in Tarnow Research Papers Collection" 2016, Vol. 32, No. 4, s. 87; M. Borkowska-Niszczota, Tourism clusters in Eastern Poland - analysis of selected aspects of the operations, „Procedia - Social and Behavioral Sciences” 2015, Vol. 213, s. 958; B. Klemens, Inicjatywy i klastry turystyczne oraz ich wptyw na rozwój regionu [w:] Przegląd nauk stosowanych, red. B. Solga, Opole 2016, s. 45.
} 
Przedstawione definicje klastrów turystycznych wskazują, że turystyka jest tą gałęzią gospodarki, w której klastry powstają w sposób naturalny ze względu na heterogeniczny i złożony charakter relacji w procesie projektowania, wytwarzania, sprzedaży, dystrybucji i konsumpcji wyrobów i usług turystycznych ${ }^{6}$. Kompleksowość oferowanych wyrobów i usług wymaga odpowiedniej infrastruktury społeczno-technicznej, bazy zasobów i kapitału intelektualnego. Tym samym rodzi to wiele zależności i powiązań pomiędzy podmiotami partycypującymi w ich tworzeniu i konsumpcji. Formalne i nieformalne relacje pionowe, poziome i diagonalne w ramach współpracy podmiotów sektora turystyki i innych powiązanych sektorów gospodarki (np. usługi finansowe, logistyczne, transportowe, medyczne oraz technologie informacyjno-komunikacyjne) powodują, że bardzo trudno jest wyznaczyć granice klastra turystycznego.

Głównymi determinantami rozwoju klastrów turystycznych są: masa krytyczna, bliskość (geograficzna, technologiczna, kulturowa, społeczna, rynkowa), koncentracja firm sektora turystycznego i sektorów pokrewnych, jakość współpracy biznesu i nauki, implementacja technologii informacyjno-komunikacyjnych, wzrost świadomości i wiedzy turystów (klientów), aktywność konsumencka i prosumpcja, poszukiwanie innowacyjnych kierunków doskonalenia wyrobów i usług turystycznych oraz rosnąca konkurencja w tym obszarze aktywności, w przestrzeni krajowej i międzynarodowej7. Podobnie uważa M. Dębski, który do zasadniczych warunków niezbędnych dla rozwoju tego typu klastrów zaliczył np.: różnorodność członków klastra, ich rzeczywistą i długookresową współpracę, koprodukcję i współtworzenie produktu turystycznego oraz otwarty charakter członkostwa w klastrze ${ }^{8}$. Pomimo że współpraca w turystyce na poziomie obszaru recepcji ruchu turystycznego wydaje się być oczywistym i naturalnym faktem, to i tak za istotną barierę rozwoju klastrów turystycznych wciąż uznaje się barierę mentalną, związaną z ograniczonym zaufaniem ich członków do potencjalnych partnerów biznesowych ${ }^{9}$. Przełamanie tej bariery jest jednym z kluczowych problemów w zarządzaniu klastrem we wstępnej fazie jego życia. Niewątpliwie spowalnia to możliwość zaistnienia synergii klastrowej.

Uwzględniając interdyscyplinarny charakter turystyki i liczne jej formy, tym łatwiej jest na gruncie teorii i praktyki turystycznego klasteringu zidentyfikować różne rodzaje klastrów turystycznych, np.:

- transgraniczne klastry turystyczne, które tworzą współpracujące ze sobą podmioty gospodarki turystycznej w przestrzeni społeczno-gospodarczej, przekraczającej co najmniej jedną granicę państwową, celem rozwoju turystyki i integracji w wymiarze terytorialnym, ekonomicznym i społeczno-kulturowym,

\footnotetext{
${ }^{6}$ E. Skowronek, Klaster jako forma..., s. 130.

${ }^{7}$ M. Borkowska-Niszczota, Wptyw klastrów turystycznych na rozwój i konkurencyjność regionów, „Zeszyty Naukowe Uniwersytetu Szczecińskiego. Ekonomiczne Problemy Turystyki” 2015, nr 2 (30), s. 148; M. Skała, K. Szpara, Rola klastrów w promocji i rozwoju turystyki na przyktadzie Innowacyjnego Klastra Zdrowie i Turystyka Uzdrowiska Perty Polski Wschodniej [w:] Rola organizacji pozarzadowych $w$ rozwoju i promocji turystyki, red. B. Sawicki, A. Nizioł, M. Obodyński, Rzeszów 2012, s. 228.

${ }^{8}$ M. Dębski M., Klaster jako czynnik rozwoju konkurencyjności destynacji turystycznej, „Przedsiębiorczość i Zarządzanie" 2014, t. XV, z. 4, cz. 3, s. 56.

${ }_{9}^{9}$ M. Januszewska, E. Nawrocka, Klaster jako narzędzie kreowania regionalnych innowacji $w$ turystyce, „Prace Naukowe Uniwersytetu Ekonomicznego we Wrocławiu” 2008, nr 29, s. 103.
} 
- klastry turystyki ekologicznej (zielonej), które działają na rzecz poprawy świadomości ekologicznej podmiotów gospodarki turystycznej oraz turystów i nie zakłócają naturalnego środowiska, przyczyniając się do jego ochrony,

- klastry agroturystyki (turystyki wiejskiej), które tworzą przede wszystkim podmioty czerpiące alternatywne do rolnictwa źródło dochodu $\mathrm{z}$ prowadzonej działalności turystycznej w warunkach wiejskich i zbliżonych do wiejskich,

- klastry turystyki kulinarnej, umożliwiające turystom poznawanie lokalnych i regionalnych tradycji kulinarnych (dziedzictwa kulinarnego), często wspomagające rozwój obszarów pozbawionych walorów przyrodniczych i kulturowych,

- klastry turystyki medycznej (zdrowotnej, uzdrowiskowej), umożliwiające turystom korzystanie z kompleksowej oferty opieki zdrowotnej i prozdrowotnej (leczenie, rehabilitacja, wypoczynek),

- klastry turystyki religijnej (pielgrzymkowej), umożliwiające turystom (pielgrzymom) łączenie mniej lub bardziej aktywnej turystyki z różnymi doznaniami religijnymi, jakie dostarczają miejsca kultu religijnego, obiekty sakralne, miejsca związane z życiem i działalnością świętych, wydarzenia religijne itp.,

- klastry turystyki biznesowej, które tworzą współpracujące ze sobą wielofunkcyjne obiekty targowo-wystawiennicze, kongresowe i konferencyjne, organizacje edukacyjne i szkoleniowe, porty lotnicze, hotele i obiekty gastronomiczne, centra rozrywkowe i sportowe (tzw. podmioty przemysłu czasu wolnego), wypożyczalnie samochodów, firmy transportowe, zapewniające korzystne warunki transportu uczestników różnych spotkań biznesowych,

- klastry turystyki morskiej, stwarzające możliwość rozwoju portów morskich poprzez sprawną obsługę morskiego ruchu turystycznego.

W wymienionych rodzajach klastrów turystycznych produktem turystycznym mogą być m.in. usługi: medyczne, dietetyczne, sanatoryjne, spa\&wellness, sportowe, agroturystyczne, wyznaniowe, transportowe ${ }^{10}$. W praktyce turystycznego klasteringu nie sposób nie zauważyć, że klastry turystyczne często unikają wąskiej specjalizacji, łącząc różne rodzaje turystyki w swym obszarze aktywności, aby osiągnąć większy efekt synergii i pełniej zaspokoić potrzeby turystów. Pozyskanie większej liczby turystów może stymulować zapotrzebowanie na różnego rodzaju usługi i przyczyniać się do powstawania nowych miejsc pracy oraz nowych form i przejawów biznesu.

Według P. Szwinty największa koncentracja przedsiębiorstw turystycznych w Polsce, sprzyjająca rozwojowi klastrów turystycznych, szczególnie zauważalna jest na obszarach przygranicznych ${ }^{11}$. Obszary te charakteryzują się z reguły zarówno różnymi przejawami peryferyjności, tj. słabą dostępnością komunikacyjną, niskim poziomem rozwoju gospodarczego, słabym zurbanizowaniem, jak i wielokulturowością i walorami przyrodniczymi. Aktywność powstających na tych obszarach turystycznych klastrów transgranicznych spójna jest z założeniami polityki współpracy międzyregionalnej Unii Europejskiej,

${ }^{10}$ B. Klemens, N. Derlukiewicz, Rola struktur klastrowych..., s. 23.

${ }^{11}$ P. Szwinta, Możliwości rozwoju transgranicznych klastrów turystycznych w Polsce, „Prace Naukowe Uniwersytetu Ekonomicznego we Wrocławiu” 2015, nr 392, s. 138-146. Współpraca polskich klastrów turystycznych z partnerami zagranicznymi wciąż nie jest powszechną dobrą praktyką. M. Leśniak, E. Wrona, Kapitat ludzki przedsiębiorstw w klastrach turystycznych w Polsce, ,Folia Pomeranae Universitatis Technologiae Stetinensis” 2016, nr 324 (82), s. 67. 
w tym sformalizowanej współpracy transgranicznej w ramach euroregionów ${ }^{12}$. W opracowaniu modelu współpracy partnerów zagranicznych w środowisku turystycznych klastrów transgranicznych bardzo ważne jest zaangażowanie koordynatorów i członków tych klastrów. Rodzi to istotne wyzwanie związane z uwzględnieniem, w tym modelu współpracy, zarówno wielowymiarowości regionu transgranicznego, jego różnych doświadczeń kulturowych, przenikania się kultur i rozwiązań w sferze społeczno-gospodarczej, jednorodności uwarunkowań przyrodniczo-geograficznych, jak również jego częstego postrzegania w kategorii regionu prowincjonalnego i zmarginalizowanego.

W literaturze przedmiotu działalność turystycznych klastrów transgranicznych z reguły prezentowana jest za pomocą studium przypadku „Szlaku Wodnego Berlin-SzczecinBałtyk" ${ }^{13}$ oraz Bieszczadzkiego Transgranicznego Klastra Turystycznego ${ }^{14}$. Rozwój tych klastrów uwarunkowany jest w znacznej mierze tożsamością regionalną. Ich cele strategiczne są podobne i dotyczą budowania partnerskiej sieci integrującej społeczność lokalną w transgranicznym regionie, poprawy jakości życia lokalnej społeczności, kreowania i promocji marki turystycznego regionu transgranicznego.

Klastry turystyczne w Polsce funkcjonują głównie w regionach uznanych za atrakcyjne przyrodniczo i kulturowo. W wyniku przeprowadzonej w 2015 roku ogólnopolskiej pogłębionej inwentaryzacji klastrów przez Polską Agencję Rozwoju Przedsiębiorczości zidentyfikowano 134 klastry działające i 106 klastrów potencjalnych, które nie spełniły wszystkich wymaganych kryteriów, aby można było uznać je za klastry działające. W grupie klastrów działających znalazło się 10 klastrów typowo turystycznych zlokalizowanych w 7 województwach kraju (podkarpackim, małopolskim, śląskim, lubuskim, pomorskim, warmińsko-mazurskim i podlaskim) oraz 10 klastrów związanych z turystyką medyczną w województwach: dolnośląskim, kujawsko-pomorskim, lubelskim, małopol-

12 A. Misztal, Rola euroregionów w rozwoju inicjatyw klastrowych, „Zeszyty Naukowe Politechniki Śląskiej. Organizacja i Zarządzanie" 2017, nr 100, s. 303-307. Współcześnie klastry transgraniczne traktowane są jako sposób wspierania konkurencyjności obszarów transgranicznych. A. Połomska-Jasienowska, Transgraniczne klastry jako forma wspótdziałania gospodarczego na pograniczu, ,Studia Ekonomiczne. Zeszyty Naukowe Uniwersytetu Ekonomicznego w Katowicach" 2016, nr 255, s. 181.

13 Turystyczny szlak wodny po stronie polskiej został zidentyfikowany w latach 90 . XX wieku w trakcie promocji regionu Doliny Dolnej Odry w Berlinie. Otwarcie granicy polsko-niemieckiej i likwidacja uciążliwych odpraw granicznych w sposób naturalny przyczyniło się do zwiększenia dostępności tej przestrzeni turystycznej. W 2007 roku produkt turystyczny „Szlak wodny BerlinSzczecin-Bałtyk" uznano za jeden z najlepszych produktów turystycznych w Polsce w ramach konkursu „Turystyka Wspólna Sprawa 2007”. W 2008 roku Grupa Partnerska „Szlak Wodny Berlin-Szczecin-Bałtyk” przekształciła się w Stowarzyszenie „Transgraniczny Klaster Turystyczny Szlak Wodny Berlin-Szczecin-Bałtyk”, aby sprawniej koordynować działalność klastra. W tym samym roku klaster otrzymał wyróżnienie Polskiej Organizacji Turystycznej w ramach konkursu „Turystyczny Produkt 2008”. Od 2011 roku w klastrze przyjęto, że jego działalność będzie zorientowana na kreowanie przedsiębiorczości przyczyniającej się do rozwoju całej gospodarki, a nie tylko turystyki w regionie transgranicznym Euroregionu Pomerania. Z. Zbroja, Szlak wodny Berlin-Szczecin-Bałtyk - szansq dla regionu transgranicznego, http://www.pomerania.org.pl/files/site/149_szlak_bszb.-1.pdf (dostęp: 12.08.2017 r.).

${ }^{14}$ Klaster powstał w ramach realizacji inicjatywy klastrowej „Polsko-ukraińska strategia rozwoju turystyki jako niezbędny element wspólnych przedsięwzięć”, sfinansowanej ze środków Europejskiego Funduszu Rozwoju Regionalnego (EFRR) Program Sąsiedztwa INTERREG IIIA/Tacis CBC Polska-Białoruś-Ukraina. K. Sala, Clusters as a form of cooperation ..., s. 92-94. 
skim, śląskim, świętokrzyskim, podlaskim i zachodniopomorskim (Klaster Innowacyjna Medycyna, Ogólnopolski Klaster e-Zdrowie, Klaster Turystyki Medycznej i Uzdrowiskowej, Lubelska Medycyna - Klaster Usług Medycznych i Prozdrowotnych, MedCluster, Ogólnopolskie Centrum Badania, Edukacji i Monitorowania Problemów Płodności, MedSilesia, Polski Innowacyjny Klaster Medyczny PIKMED, Zachodniopomorski Klaster Medyczny iSynergia, Klaster Nauka, Medycyna i Nowoczesne Technologie). Aktywność klastra turystyki medycznej i uzdrowiskowej w województwie kujawsko-pomorskim spójna jest $\mathrm{z}$ inteligentną specjalizacją regionalną, dotyczącą usług medycznych i turystyki zdrowotnej. Z kolei aktywność klastrów turystycznych z województw lubuskiego i podkarpackiego zbieżna jest z szeroko określoną inteligentną specjalizacją, dotyczącą jakości życia, zdrowia i ekorozwoju. W grupie 106 klastrów potencjalnych zidentyfikowano 12 klasycznych klastrów turystycznych i 5 klastrów turystyki medycznej ${ }^{15}$.

Analizując deklaracje misji wybranych klastrów turystycznych nie sposób było nie zauważyć, że powszechne jest w nich odniesienie do współpracy międzysektorowej, partnerstwa terytorialnego, rozwoju opartego na wiedzy i innowacjach (tabela 1). Klastry turystyczne bardzo często w swej misji podkreślają swoje znaczenie i swoją wartość dla rozwoju zrównoważonego nie tylko swoich członków, ale także regionu i sektora turystyki. Ich cele strategiczne dotyczą m.in. wzmocnienia innowacyjności i konkurencyjności, zintegrowania klastrowej oferty turystycznej, identyfikowania nisz rynkowych i kreowania adekwatnych do nich specjalistycznych produktów turystycznych.

Problematyka klastrów turystycznych jest obecnie bardzo popularna, gdyż dostrzega się szerokie spectrum korzyści, jakie dostarczają aktywnie działające klastry. Niejednokrotnie powstawanie i rozwój tej grupy klastrów kojarzy się z istnieniem określonych atrakcji i infrastruktury turystycznej oraz samym charakterem turystyki na danym obszarze. Zwykle walory turystyczne przyciągają turystów do danego regionu, a wokół nich osiedlają się podmioty świadczące zróżnicowane usługi turystyczne i rozwija się infrastruktura niezbędna do konsumpcji tych walorów turystycznych ${ }^{16}$. Współpraca klastrowa w zakresie turystyki może pozytywnie wpływać na lokalną społeczność, szczególnie na obszarach wiejskich i małych miast, gdzie w turystyce upatruje się szansy na rozwój społeczno-gospodarczy ${ }^{17}$. H. Howaniec i J. Kurowska-Pysz uważają, że rozwój klastrów turystycznych w regionie przyczynia się do wzrostu znaczenia gospodarczego regionu, a poprzez to także do poprawy zagospodarowania turystycznego i atrakcyjności turystycznej ${ }^{18}$. Jednakże, aby klastry turystyczne mogły odegrać znaczącą rolę w aktywizacji

15 G. Buczyńska, D. Frączek, P. Kryjom, Raport z inwentaryzacji klastrów w Polsce w 2015, Warszawa 2016, s. 7-38.

16 A. Gardzińska, T. Mańkowski, Międzynarodowy morski klaster turystyczny jako narzędzie wspierające rozwój turystyki morskiej, „Zeszyty Naukowe Uniwersytetu Szczecińskiego. Ekonomiczne Problemy Turystyki” 2013, nr 4 (24), s. 15. Funkcjonowanie klastra turystycznego na danym terytorium może generować także potencjalnie negatywne efekty: nadmierna koncentracja ruchu turystycznego, dyskryminacja słabszych członków klastra lub podmiotów spoza klastra, stopniowe ograniczanie autonomii członków klastra, kształtowanie obszarów monokultury turystycznej, które są wrażliwe na zmiany koniunktury. A. Kołodziejczak, Inicjatywy klastrowe..., s. 141.

${ }^{17}$ K. Firlej, A. Rożek, Korzyśsi z klasteringu transgranicznego jako innowacyjnej formy rozwoju ustug turystycznych na obszarach przygranicznych Polski Potudniowo-Wschodniej, „Zeszyty Naukowe Uniwersytetu Ekonomicznego w Krakowie” 2012, nr 891, s. 42.

${ }^{18}$ H. Howaniec, J. Kurowska-Pysz, Klaster jako instrument rozwoju polsko-stowackiej wspótpracy transgranicznej, Dąbrowa Górnicza 2014, s. 23. 
społeczności lokalnej, poprawie spójności gospodarczej i społecznej, przekształceniu danego regionu w region turystyczny, stymulowaniu ruchu turystycznego i wzmacnianiu konkurencyjności regionalnej turystyki, niezbędne jest zaangażowanie lokalnych i regionalnych władz samorządowych w tworzenie korzystnych warunków dla rozwoju tego typu klastrów oraz pokonywanie różnych barier, w tym tych mentalnych ${ }^{19}$. Bez wątpienia konieczne jest prawidłowe zrozumienie istoty klasteringu i sposobu kształtowania kapitału społecznego, w tym norm grupowych, w tej formie partnerstwa terytorialnego ${ }^{20}$.

Tabela 1. Deklaracje misji wybranych klastrów turystycznych w Polsce

\begin{tabular}{|c|l|}
\hline Nazwa klastra & \multicolumn{1}{c|}{ Misja } \\
\hline $\begin{array}{c}\text { Klaster Marek } \\
\text { Turystycznych } \\
\text { Polski Wschodniej } \\
\text { „W sercu natury” }\end{array}$ & $\begin{array}{l}\text { Wspieranie instytucji i przedsiębiorców działających w obszarze tury- } \\
\text { styki biznesowej i zdrowotnej oraz usług szkoleniowych i rekreacyjno- } \\
\text { sportowych poprzez stworzenie trwałych ram współpracy opartej na } \\
\text { transferze wiedzy, technologii i innowacji pomiędzy członkami klastra, } \\
\text { samorządami, podmiotami otoczenia biznesu i sektora B+R. }\end{array}$ \\
\hline $\begin{array}{c}\text { Klaster } \\
\text { Aktywnej Turystyki }\end{array}$ & $\begin{array}{l}\text { Rozwój i promocja turystyki, aktywnego wypoczynku, zdrowego stylu } \\
\text { życia, walorów turystycznych Polski oraz jej regionów i subregionów. }\end{array}$ \\
\hline $\begin{array}{c}\text { Przemyski } \\
\text { Klaster Turystyczny }\end{array}$ & $\begin{array}{l}\text { Rozwój platformy współdziałania przedsiębiorstw, organizacji pozarzą- } \\
\text { dowych, instytucji publicznych, szkół i innych zainteresowanych pod- } \\
\text { miotów w celu skutecznego i efektywnego zwiększenia atrakcyjności } \\
\text { turystycznej Przemyśla i regionu oraz podnoszenia innowacyjności } \\
\text { i konkurencyjności członków klastra. }\end{array}$ \\
\hline $\begin{array}{c}\text { Karkonosko-Izerski } \\
\text { Klaster Turystyczny }\end{array}$ & $\begin{array}{l}\text { Wspieranie rozwoju branży turystycznej, budowa marki regionu Karko- } \\
\text { nosko-Izerskiego i realizowanie wspólnych celów członków klastra } \\
\text { poprzez stworzenie trwałych ram współpracy opartej na transferze wie- } \\
\text { dzy, technologii i innowacji oraz wspólnym potencjale przedsiębiorców, } \\
\text { instytucji otoczenia biznesu, podmiotów sektora B+R i samorządów. }\end{array}$ \\
\hline $\begin{array}{c}\text { Klaster Turystyczny } \\
\text { „Szlak Piastowski } \\
\text { w Wielkopolsce” }\end{array}$ & $\begin{array}{l}\text { Koordynacja unikatowego Szlaku Piastowskiego na terenie wojewódz- } \\
\text { twa wielkopolskiego, kreowanie jego atrakcyjnego wizerunku w prze- } \\
\text { strzeni krajowej i międzynarodowej celem zwiększenia liczby turystów } \\
\text { odwiedzających szlak i region, wydłużenia ich czasu pobytu i optymali- } \\
\text { zacji dochodów z turystyki. }\end{array}$ \\
\hline
\end{tabular}

Źródło: opracowanie własne na podstawie: www.klasterturystyczny.pl; www.szlakpiastowski.pl; www.klasteraktywnejturystyki.pl; www.perlagalicji.pl; www.karr.pl.

Klastry turystyczne mogą stymulować rozwój lokalnej gospodarki nie tylko poprzez wzmacnianie potencjału strategicznego swoich członków, ale także poprzez kreowanie przedsiębiorczego ekosystemu sprzyjającego powstawaniu nowych form i przejawów działalności biznesowej w turystyce. Aby klaster turystyczny mógł być fundamentem

${ }^{19}$ M. Roman, Klastry jako forma wspótdziałania w działalności turystycznej, „Zarządzanie i Finanse" 2013, t. 11, nr 1, cz. 3, s. 318; M. Dębski, Klaster jako czynnik rozwoju konkurencyjności destynacji turystycznej, „Przedsiębiorczość i Zarządzanie” 2014, t. XV, z. 4, cz. 3, s. 55.

${ }^{20}$ S. Gardiner, N. Scott, Successful tourism clusters: passion in paradise, „Annals of Tourism Research" 2014, No. 46, s. 172. 
inteligentnej specjalizacji oraz wzrostu gospodarczego danego regionu ${ }^{21}$, musi być konkurencyjny wobec innych klastrów w przestrzeni krajowej i międzynarodowej. Z chwilą, gdy koncentracja specyficznych zasobów materialnych i niematerialnych w kluczowym sektorze klastra na danym terytorium i w określonym czasie pozwala na kreowanie efektu synergii w procesie wytwarzania i sprzedaży produktów turystycznych, wówczas staje się on atrakcyjnym środkiem oddziaływania na otoczenie i pozyskiwania nowych zasobów, $\mathrm{w}$ tym inwestycji zagranicznych ${ }^{22}$. Ponadto jego konkurencyjność wyraża się w skali aktywizacji społeczności lokalnej w zrównoważonym rozwoju zintegrowanego produktu turystycznego oraz we wdrażaniu i upowszechnianiu innowacji społecznych, istotnych z punktu widzenia potrzeb społecznych i rynku turystycznego.

\section{KLASTROWY PRODUKT TURYSTYCZNY}

Pojęcie klastrowego produktu turystycznego powstało na bazie stosowanego znacznie wcześniej w turystyce pojęcia produktu turystycznego odnoszonego do regionu, obszaru, miejsca czy recepcji turystycznej. Używanie wymiennie pojęć regionalnego produktu turystycznego i klastrowego produktu turystycznego nie jest poprawne pomimo pewnej zbieżności terminologicznej, gdyż w danym regionie może funkcjonować kilka klastrów turystycznych, oferujących w różnym stopniu zintegrowane produkty. Przyjmuje się, że regionalny produkt turystyczny to pojęcie znacznie szersze znaczeniowo ${ }^{23}$. Obejmuje ono wszystkie atrakcje turystyczne występujące w danym regionie, w tym także te, których powstanie nie wiąże się z aktywnością klastrów.

Klastrowym produktem turystycznym może być pojedyncza usługa turystyczna oferowana turyście przez członków klastra turystycznego lub pakiet świadczeñ ${ }^{24}$. W tym drugim przypadku współtworzą go różne, zintegrowane ze sobą dobra i usługi turystyczne oferowane turystom w obszarze zakorzenienia klastra. Jakość współpracy w klastrowym łańcuchu wartości i zaangażowanie koordynatora klastra, pozwala na stworzenie takiego zestawu dóbr i usług, który zarówno wykorzystuje lokalne zasoby, jak i jest odpowiednio atrakcyjny dla klientów-turystów, dostarczając im pozytywnych wrażeń i doświadczeń25

${ }^{21}$ K. Sikora, Klastry turystyczne szansa rozwoju mikroregionów, „Zarządzanie i Finanse” 2012, Vol. 10, nr 1, cz. 2, s. 64.

${ }^{22}$ M. Roman, Wptyw klastrów turystycznych na innowacyjność gospodarki turystycznej, „Studia i Prace Wydziału Nauk Ekonomicznych i Zarządzania Uniwersytetu Szczecińskiego” 2017, nr $48 / 3$, s. 55-56.

${ }^{23}$ H. Howaniec, J. Kurowska-Pysz, Klaster jako instrument rozwoju..., s. 66.

${ }^{24}$ A. Rapacz, Rola klastrów w kształtowaniu struktury i jakości produktu turystycznego regionu, „Prace Naukowe Uniwersytetu Ekonomicznego we Wrocławiu” 2008, nr 29, s. 109; J. Staszewska, Klaster perspektywa dla przedsiębiorców na polskim rynku turystycznym, Warszawa 2009, s. 74.

25 Wspieranie członków klastra w zakresie łańcuchów wartości stanowi jeden z 36 podstawowych standardów zarządzania klastrem w Polsce. Przyjmuje się, że standard ten jest spełniony, gdy przynajmniej w jednym w trzech obszarów koordynator wspiera rozwój klastrowego łańcucha wartości. Po pierwsze, koordynator może wspierać procesy dokonywania wspólnych zamówień w klastrze. Po drugie, może wspierać procesy wspólnej sprzedaży, agregując indywidualne oferty członków klastra i negocjując warunki sprzedaży. Po trzecie, może wspierać różne procesy tworzenia wartości w klastrze np. w obszarze logistyki, promocji, B+R. Zachowanie tego standardu może przełożyć się na konkurencyjność, rozwój i efekty ekonomiczne klastra, w tym jego członków. Standardy zarządzania klastrem opracowała grupa ekspertów pod kierownictwem meryto- 
Wspólny produkt członków klastra turystycznego ponadto charakteryzuje się złożonością i zmiennością w czasie, gdyż uwarunkowany jest w znacznej mierze potrzebami klientówturystów, atrakcjami i walorami turystycznymi, infrastrukturą turystyczną, jakością obsługi i konkurencyjnością cenową, ukształtowanym wizerunkiem obszaru klastra (regionu turystycznego). Tym samym wymaga stałego wzbogacania i modyfikowania o nowe wartości, zgodnie z cyklem życia i zmieniającymi się potrzebami turystó ${ }^{26}$.

Jakość klastrowego produktu turystycznego, złożonego z wielu komplementarnych wyrobów i usług świadczonych przez wyspecjalizowanych dostawców w ramach klastra turystycznego wymaga sprawnej współpracy wewnętrzklastrowej oraz obsługi turystów. Rdzeniem klastrowego produktu turystycznego oferowanego w danym regionie mogą być np. tradycje kulinarne i gospodarcze, oryginalny obiekt lub szlak, walory przyrodnicze i społeczno-kulturowe ${ }^{27}$. Zarówno atrakcje naturalne (krajobraz, ukształtowanie terenu, klimat), stworzone przez człowieka (budynki, infrastruktura zabytkowa), kulturalne (tradycja i folklor, religia, muzea, imprezy tematyczne), jak i społeczne, odnoszące się do jakości życia lokalnej społeczności, mogą być źródłem wielu różnych wartościowych koncepcji klastrowych produktów turystycznych ${ }^{28}$.

Jednym z wielu atrybutów sprawnie działającego klastra turystycznego na danym obszarze jest jego zdolność do kreowania i komercjalizacji klastrowego produktu turystycznego. Zapewniając przedsiębiorczy ekosystem dla rozwoju tego typu produktu, wymagającego współpracy w ramach turystycznego łańcucha wartości, członkowie klastra dążą do połączenia jakości i innowacyjności ze specyficznymi cechami regionu swojego zakorzenienia, w tym jego walorami przyrodniczymi i dziedzictwem kulturowo-historycznym. Wewnętrzny system komunikacji klastra turystycznego, oparty na kapitale społecznym, sprzyja rozwojowi struktury łańcucha wartości produktu turystycznego, odpowiadającego na dynamicznie zmieniające się potrzeby i oczekiwania turystów oraz innych interesariuszy. Umiejętne wykorzystanie potencjału technologii informacyjnokomunikacyjnej (ICT), w tym mniej lub bardziej rozbudowanych i funkcjonalnych platform crowdsourcingowych, pozwala m.in. interesariuszom zewnętrznym (np. turystom-klientom) dzielić się wiedzą i swoimi pomysłami. W ten sposób angażujący się interesariusze mogą mieć realne poczucie satysfakcji ze swojego udziału w kreowaniu klastrowego produktu turystycznego. Współczesne przedsiębiorcze podejście do klienta zewnętrznego (turysty) w klastrze turystycznym wymaga pełnej świadomości, że klient nie tylko oczekuje wartości, ale sam ją oferuje ${ }^{29}$.

rycznym Polskiej Agencji Rozwoju Przedsiębiorczości (PARP) w 2014 roku. Tworzą one zbiór zasad określających pożądane cechy zarządzania klastrem i aktywności klastrów oraz stymulujących poprawę jakości zarządzania klastrami. M. Piotrowski, Standardy zarządzania klastrem, PARP, Warszawa 2014, s. 32.

${ }^{26}$ M. Roman, J. Zawadka, Klaster okopski jako forma innowacyjnych działań w agroturystyce [w:] Gospodarka polska po 20 latach transformacji, red. S. Pangsy-Kania, G. Szczodrowski, Warszawa 2009, s. 391.

${ }^{27}$ L. Kaliszczak, Klaster turystyczny jako innowacyjna forma polsko-ukraińskiej wspótpracy transgranicznej, „Przedsiębiorstwo i Region” 2009, nr 1, s. 99.

${ }^{28}$ R. Kusa, Uwarunkowania rozwoju klastrów turystycznych [w:] Zarzadzanie organizacjami w gospodarce opartej na wiedzy, Toruń 2008, s. 514.

${ }_{29}$ T. Burzyński, D. Dryglas, M. Cembruch-Nowakowski, Łańcuch wartości w turystyce oparty na wiedzy [w:] Konsument na rynku turystycznym $w$ gospodarce opartej na wiedzy $i$ informacji, red. T. Burzyński, Katowice 2005, s. 122. 
Turystyczny łańcuch wartości klastra jest fundamentem tworzenia zintegrowanego produktu turystycznego ${ }^{30}$. Integrowanie wielu różnych atrakcji i walorów turystycznych o wspólnych korzeniach historczno-kulturowych w ramach danego regionu dostarcza efektu synergii w zakresie promocji, obsługi klienta i redukcji kosztów transakcyjnych ${ }^{31}$. W efekcie tego typu aktywności klastra turystycznego wcześniej nieistniejące lub mało znane i wypromowane atrakcje turystyczne mogą być postrzegane w inny sposób oraz częściej i chętniej wybierane przez turystów. Ponadto zaistnienie nowych obiektów na turystycznej mapie, cieszących się zainteresowaniem szerokiej grupy turystów, może w znacznym stopniu odmienić oblicze danego terytorium. Wzmacnianie mocnych stron klastrowego produktu turystycznego oferowanego na danym terytorium, jednocześnie prowadzi do intensyfikacji efektów zewnętrznych zgodnie z efektem rozlewania (tzw. spill-over $)^{32}$. O słuszności decyzji dotyczącej koncentracji sił i środków członków klastra turystycznego $\mathrm{w}$ procesie kreowania ich wspólnego i oryginalnego produktu związanego z obszarem ich zakorzenienia świadczy fakt, że turysta zwykle oczekuje odpowiednio kompleksowej i zintegrowanej oferty, spójnej tematycznie z wybraną destynacją, która jest źródłem pozytywnych wrażeń i nowych doświadczeń ${ }^{33}$.

Analizując aktywność klastrów turystycznych w zakresie kształtowania klastrowego produktu turystycznego, nie sposób nie przedstawić konkretnej dobrej praktyki w tym obszarze. Takiego przykładu dostarcza m.in. metaklaster turystyki kulinarnej powstały poprzez sieciowanie międzyklastrowe Klastra Podkarpackie Smaki ${ }^{34}$ i Karpackiego Klastra Turystycznego ${ }^{35}$. Współpraca strategiczna członków i koordynatora tych klastrów

${ }^{30}$ M. Słomińska-Okła, Klastry determinanta innowacyjności regionów w Polsce i na Ukrainie [w:] Wschód i Zachód w wymiarze globalnym, red. M. Miłek, D. Wilk-Jakubowski, R. Brzoza, Kielce 2012, s. 154.

${ }^{31}$ B. Klemens, Inicjatywy i klastry turystyczne..., s. 49.

${ }^{32}$ P. Brambert, A. Zieliński, Atrakcje a możliwości rozwoju klastra turystycznego na przykładzie południowo-wschodniej części regionu świętokrzyskiego, „Prace Naukowe Uniwersytetu Ekonomicznego we Wrocławiu" 2017, nr 473, s. 112.

33 A. Kołodziejczak, Inicjatywy klastrowe..., s. 141.

${ }^{34}$ Klaster Podkarpackie Smaki współtworzą współpracujący ze sobą producenci żywności regionalnej, tradycyjnej i ekologicznej. Klaster działa od 2013 roku w województwie podkarpackim. Obecnie zrzesza 54 podmioty, w tym obiekty gastronomiczne z lokalnymi i tradycyjnymi daniami. Celem strategicznym klastra jest aktywne wspieranie producentów żywności poprzez pozyskiwanie środków zewnętrznych, działania szkoleniowe, integrację ze środowiskiem naukowym oraz promocję produktów członków klastra w przestrzeni krajowej (np. Festiwal Podkarpackich Smaków) i międzynarodowej (np. aktywny udział w wizytach studyjnych, projektach i targach międzynarodowych). Województwo podkarpackie wyróżnia się w kraju pod względem ilości i jakości produktów regionalnych i tradycyjnych. M. Pisarek, J. Lechowska, Znaczenie klastra Podkarpackie Smaki w rozwoju regionalnej turystyki kulinarnej, „Studia Komitetu Przestrzennego Zagospodarowania Kraju Polskiej Akademii Nauk” 2015, t. CLXII, s. 230-238.

35 Karpacki Klaster Turystyczny zorientowany jest na rozwój współpracy podmiotów gospodarki turystycznej na rzecz wzmocnienia konkurencyjności turystyki w województwie podkarpackim. Ma charakter otwarty, przez co do współpracy klastrowej mogą przyłączyć się wszystkie zainteresowane podmioty działające w segmencie turystyki aktywnej, kulturowej, przyrodniczej, zdrowotnej i kulinarnej, w tym związane z turystyką podmioty sektora B+R i instytucje otoczenia biznesu. Organami klastra są: Zgromadzenie Członków Klastra, Rada Klastra, Animator Klastra i Rada Naukowa Klastra. Majątek członków klastra tworzą m.in. środki pochodzące 
tj. Stowarzyszenia na rzecz Rozwoju i Promocji Podkarpacia „Pro Carpathia” z Urzędem Marszałkowskim Województwa Podkarpackiego i Podkarpacką Regionalną Organizacją Turystyczną pozwoliła na opracowanie zintegrowanego produktu turystycznego pod nazwą „Szlak Kulinarny Podkarpackie Smaki” ${ }^{36}$. Początkowo w 2013 roku tworzyło go 39 obiektów gastronomicznych. Po czterech latach - już 50, w tym 41 restauracji, 3 winnice, 3 cukiernie i 3 gospodarstwa agroturystyczne. Klastrowy produkt turystyczny zapewnia turystom jedną $\mathrm{z}$ najdłuższych tras kulinarnych $\mathrm{w}$ Polsce w ramach turystyki kulinarnej (trasa bieszczadzka, beskidzko-podgórzańska i północna). Podróż tym szlakiem to swoiste "smakowanie regionu", poznawanie tradycji kulinarnych Podkarpacia, w tym kuchni łemkowsko-bojkowskiej, etnicznej, włościańskiej, mieszczańskiej, dworskiej oraz kuchni fusion-autorskiej, łączącej tradycyjne przepisy kulinarne ze współczesnym do nich podejściem ${ }^{37}$. Warto zaznaczyć, że każdy obiekt na szlaku kulinarnym przechodzi proces certyfikacji i oferuje co najmniej trzy potrawy ekologiczne, regionalne lub tradycyjne (np. proziaki, hreczanyki, fuczki, klepaki, stolniki, przekładaniec, chopcie, chrzanicę, zalewajkę, pierogi z dziczyzną, dołmę tatarską, pieczoną gicz baranią). W siedmiu wybranych obiektach szlaku w sprzedaży znajdują się produkty ekologiczne, regionalne oraz tradycyjne klastrowych producentów, odpowiednio wyeksponowane na specjalnie oznakowanej półce z logo „Podkarpackie Smaki”. Niektóre z oferowanych produktów mają zapewnioną chronioną nazwę pochodzenia. Dla ułatwienia podróży kulinarnej po tak atrakcyjnym i wszechstronnym szlaku opracowano przewodnik kulinarno-turystyczny w ramach projektu „Alpejsko-Karpacki Most Współpracy”, współfinansowanego przez Szwajcarię (Szwajcarski Program Współpracy z Nowymi Krajami Członkowskimi UE). Druga edycja tego bezpłatnego przewodnika zawierała opis 50 obiektów znajdujących się na multikulturowym szlaku kulinarnym.

Zintegrowany produkt turystyczny promuje zarówno bardzo aktywne poznawanie regionu zakorzeniania metaklastra, jak i zapewnia pozytywne wrażenia i doświadczenia turystom, związane z konsumpcją oraz bogatą tradycją kulinarną. W 2014 roku produkt ten otrzymał tytuł najlepszego produktu turystycznego regionu Podkarpacia nadany przez Podkarpacką Regionalną Organizację Turystyczną. Doceniono w ten sposób jego rolę w propagowaniu historii regionalnych kulinariów oraz wpływ na zwiększenie atrakcyjności ofert członków metaklastra. Ponadto doceniono jego kompleksowość, atrakcyjność i nowatorstwo w promowaniu dziedzictwa kulinarnego, co pomaga jednocześnie w rozwoju turystyki, poprawie atrakcyjności oferty turystycznej województwa podkarpackiego i rozwoju drobnej przedsiębiorczości m.in. na obszarach wiejskich i mniejszych miast. Tym samym władze samorządowe wraz z koordynatorem metaklastra turystyki kulinarnej uważają, że bogata i atrakcyjna oferta kulinarna Podkarpacia jest bardzo dobrą przesłanką do budowy silnego, markowego produktu turystyki regionalnej ${ }^{38}$. Warto podkreslić, że

ze składek członkowskich, http://www.procarpathia.pl/pl/karpacki_klaster_turystyczny/ (dostęp: 1.08.2017 r.).

${ }^{36} \mathrm{http}: / / w w w . p o d k a r p a c k i e s m a k i . p l / p l / k u l i n a r i a-p o d k a r p a c k i e / a k t u a l n o s c i / a r t 816$, szlak-kulinarnypodkarpackie-smaki.html (dostęp: 1.08.2017 r.).

37 http://www.szlakpodkarpackiesmaki.pl (dostęp: 1.08.2017 r.).

${ }^{38}$ Przyjęto także, że lokale gastronomiczne w środowisku metaklastra turystyki kulinarnej stanowią strategiczne ogniwo zintegrowanej oferty miejsca, wpływając silnie na wizerunek konkurencyjnej destynacji biznesowej i turystycznej, http://praca.wrotapodkarpackie.pl/index.php/32-turystyka/ 76-szlak-kulinarny-podkarpackie-smaki (dostęp: 1.08.2017 r.). 
w 2017 roku „Szlak Kulinarny Podkarpackie Smaki” zaliczono do atrakcji turystycznych określonych mianem „7 Nowych Cudów Polski” w ramach ogólnopolskiego plebiscytu realizowanego przez czasopismo turystyczne National Geographic Traveler ${ }^{39}$.

Przedstawiony przykład pomyślnie opracowanego i skomercjalizowanego klastrowego produktu turystycznego potwierdza dwie tezy. Po pierwsze, uzyskanie wysokiej jakości ${ }^{40}$ oraz materialnej i niematerialnej wartości tego produktu dla jego interesariuszy, wymaga strategicznego partnerstwa terytorialnego, zgodnego z wizją i kierunkami rozwoju regionu zakorzenienia klastra. Po drugie, wymierne wsparcie władz publicznych jest tym bardziej możliwe, im bardziej klastrowy produkt jest zintegrowany i przyczynia się do budowania silnej marki miejsca oraz rozwoju społeczno-gospodarczego.

\section{ZAKOŃCZENIE}

Współczesne zmiany zachodzące na krajowym i globalnym rynku turystycznym oraz w obszarze europejskiej i polskiej polityki klastrowej stwarzają nie tyle potrzebę, co konieczność stałego doskonalenia zarządzania klastrami turystycznymi. Nie wszystkie bowiem klastry turystyczne wykazują zdolność do dynamicznego rozwoju, w tym oferowania turystom własnego, mniej lub bardziej zintegrowanego produktu turystycznego.

Punktem wyjścia w procesie projektowania i komercjalizacji klastrowego produktu turystycznego jest określenie zakresu aktywności klastra turystycznego, jego uwarunkowań rozwoju (ekonomicznych, polityczno-prawnych, społeczno-kulturowych, ekologicznych, technologicznych), które w znacznym stopniu determinują atrakcyjność turystyczną jego terytorium zakorzenienia. W procesie tym niezbędne są także takie działania jak:

- zapewnienie wysokiej jakości oferty klastra, na którą składają się atrakcje i ich dostępność, usługi dodatkowe, twarda i miękka infrastruktura turystyczna,

- stworzenie koncepcji zintegrowanego produktu turystycznego,

- zapewnienie korzystnych warunków do rozwoju współpracy klastrowej, w tym tej w modelu partnerstwa publiczno-prywatnego i międzynarodowego,

- pozyskanie niezbędnych zasobów,

- angażowanie do projektów klastrowych wielu różnych podmiotów związanych z turystyką ze środowiska biznesu, instytucji okołobiznesowych i sektora B+R,

- pozyskanie inwestorów i wymiernego wsparcia władz samorządowych,

- identyfikowanie potrzeb kluczowych interesariuszy wewnętrznych klastra (np. członków, przedstawicieli organów władzy i koordynatora) i zewnętrznych (np. inwestorów, władz samorządowych, polityków, partnerów, turystów),

- badanie satysfakcji klientów-turystów i prognozowanie popytu turystycznego w regionie klastra,

39 W plebiscycie brało udział 32 kandydatów. Szlak Kulinarny Podkarpackie Smaki zajął ostatecznie 7. miejsce w głosowaniu internautów, http://rzeszow.wyborcza.pl/rzeszow/ 7,34962,22342165,szlak-kulinarny-podkarpackie-smaki-doceniony-jest-jednym-z.html (dostęp: 8.09.2017 r.).

40 Jakość produktu klastrowego odnosi się do cech zewnętrznych, tj. wymaganych i ocenianych przez klienta oraz innych interesariuszy klastra, a także wewnętrznych aspektów technicznotechnologicznych, organizacyjnych, ekonomicznych, społecznych i środowiskowych tworzenia produktu. J. Maciąg, Jakość sieciowego produktu turystycznego - definiowanie, wymiary i cechy jakościowe, „Studia Ekonomiczne. Zeszyty Naukowe Uniwersytetu Ekonomicznego w Katowicach" 2015, nr 215, s. 50. 
- ciągłe identyfikowanie i eliminowanie barier rozwoju współpracy klastrowej, natury organizacyjnej, finansowej i mentalnej,

- ciągłe uczenie się w oparciu o najlepsze praktyki klastrów poprzez stosowanie benchmarkingu w przestrzeni krajowej i międzynarodowej,

- połączenie jakości i innowacyjności klastrowego produktu turystycznego ze specyficznymi cechami regionu zakorzenienia klastra, w tym jego walorami przyrodniczymi oraz wielowymiarowym dziedzictwem kulturowo-historycznym,

- implementacja założeń zarządzania strategicznego i marketingowego, pozwalających na właściwe opracowanie strategii rozwoju klastra i jej wdrażanie z użyciem podstawowych elementów i narzędzi marketingu,

- dynamiczne zarządzanie klastrem oparte na angażującym przywództwie.

Konkludując, należy stwierdzić, że zarówno kluczowe atrybuty klastrowego produktu turystycznego (np. sieciowość, złożoność, nietrwałość, zmienność, kompleksowość), jak i przykłady wymienionych działań podejmowanych dla jego stworzenia i komercjalizacji, świadzą o istotnym wyzwaniu strategicznym w zarządzaniu klastrem turystycznym. Sprostanie temu wyzwaniu w obliczu zaostrzającej się walki konkurencyjnej pomiędzy destynacjami wymaga w znacznej mierze twórczego myślenia i sprawnego działania kluczowych wewnętrznych i zewnętrznych interesariuszy klastra turystycznego.

\section{LITERATURA}

[1] Borkowska-Niszczota M., Tourism clusters in Eastern Poland - analysis of selected aspects of the operations, "Procedia - Social and Behavioral Sciences" 2015, Vol. 213, s. 957-964.

[2] Borkowska-Niszczota M., Wptyw klastrów turystycznych na rozwój i konkurencyjność regionów, ,Zeszyty Naukowe Uniwersytetu Szczecińskiego. Ekonomiczne Problemy Turystyki" 2015 , nr 2 (30), s. 145-164.

[3] Brambert P., Zieliński A., Atrakcje a możliwości rozwoju klastra turystycznego na przykładzie południowo-wschodniej części regionu świętokrzyskiego, „Prace Naukowe Uniwersytetu Ekonomicznego we Wrocławiu" 2017, nr 473, s. 107-116.

[4] Buczyńska G., Frączek D., Kryjom P., Raport z inwentaryzacji klastrów w Polsce w 2015, PARP, Warszawa 2016.

[5] Burzyński T., Dryglas D., Cembruch-Nowakowski M., Łańcuch wartości w turystyce oparty na wiedzy [w:] Konsument na rynku turystycznym $w$ gospodarce opartej na wiedzy $i$ informacji, red. T. Burzyński, Wydawnictwo Górnośląskiej Wyższej Szkoły Handlowej w Katowicach, Katowice 2005.

[6] Dębski M., Klaster jako czynnik rozwoju konkurencyjności destynacji turystycznej, „Przedsiębiorczość i Zarządzanie" 2014, t. XV, z. 4, cz. 3, s. 51-66.

[7] Firlej K., Rożek A., Korzyści z klasteringu transgranicznego jako innowacyjnej formy rozwoju ustug turystycznych na obszarach przygranicznych Polski Potudniowo-Wschodniej, ,Zeszyty Naukowe Uniwersytetu Ekonomicznego w Krakowie” 2012, nr 891, s. 31-51.

[8] Gardiner S., Scott N., Successful tourism clusters: passion in paradise, "Annals of Tourism Research" 2014, No. 46, s. 171-173.

[9] Gardzińska A., Mańkowski T., Międzynarodowy morski klaster turystyczny jako narzędzie wspierające rozwój turystyki morskiej, „Zeszyty Naukowe Uniwersytetu Szczecińskiego. Ekonomiczne Problemy Turystyki” 2013, nr 4 (24), s. 9-21. 
[10] Howaniec H., Kurowska-Pysz J., Klaster jako instrument rozwoju polsko-stowackiej wspótpracy transgranicznej, Wyższa Szkoła Biznesu w Dąbrowie Górniczej, Dąbrowa Górnicza 2014.

[11] http://klasteraktywnejturystyki.pl (dostęp: 1.08.2017 r.).

[12] http://praca.wrotapodkarpackie.pl/index.php/32-turystyka/76-szlak-kulinarny-podkarpackie-smaki (dostęp: 1.08.2017 r.).

[13] http://rzeszow.wyborcza.pl/rzeszow/7,34962,22342165,szlak-kulinarny-podkarpackiesmaki-doceniony-jest-jednym-z.html (dostęp: 8.09.2017 r.).

[14] http://www.karr.pl/turystyka/karkonosko-izerski-klaster-turystyczny (dostęp: 1.08.2017 r.).

[15] http://www.klasterturystyczny.pl (dostęp: 1.08.2017 r.).

[16] http://www.perlagalicji.pl/przemyski-klaster-turystyczny (dostęp: 1.08.2017 r.).

[17] http://www.podkarpackiesmaki.pl/pl/kulinaria-podkarpackie/aktualnosci/art816,szlakkulinarny-podkarpackie-smaki.html (dostęp: 1.08.2017 r.).

[18] http://www.procarpathia.pl/pl/karpacki_klaster_turystyczny/ (dostęp: 1.08.2017 r.).

[19] http://www.szlakpodkarpackiesmaki.pl (dostęp: 1.08.2017 r.).

[20] Januszewska M., Nawrocka E., Klaster jako narzędzie kreowania regionalnych innowacji $w$ turystyce, „Prace Naukowe Uniwersytetu Ekonomicznego we Wrocławiu” 2008, nr 29, s. 95-105.

[21] Kaliszczak L., Klaster turystyczny jako innowacyjna forma polsko-ukraińskiej wspótpracy trans granicznej, „Przedsiębiorstwo i Region” 2009, nr 1, s. 97-106.

[22] Klemens B., Derlukiewicz N., Rola struktur klastrowych w rozwoju miast w perspektywie 2020 (aspekt turystyczny), „Studia Miejskie” 2014, t. 16, s. 19-35.

[23] Klemens B., Inicjatywy i klastry turystyczne oraz ich wptyw na rozwój regionu [w:] Przeglad nauk stosowanych, red. B. Solga, Oficyna Wydawnicza Politechniki Opolskiej, Opole 2016.

[24] Kołodziejczak A., Inicjatywy klastrowe jako narzędzie regionalnego rozwoju turystyki, „Studia Komitetu Przestrzennego Zagospodarowania Kraju Polskiej Akademii Nauk” 2016, t. CLXXII, s. 137-148.

[25] Kusa R., Uwarunkowania rozwoju klastrów turystycznych [w:] Zarządzanie organizacjami w gospodarce opartej na wiedzy, Wydawnictwo Uniwersytetu Mikołaja Kopernika w Toruniu, Toruń 2008.

[26] Leśniak M., Wrona E., Kapitat ludzki przedsiębiorstw w klastrach turystycznych w Polsce, „Folia Pomeranae Universitatis Technologiae Stetinensis” 2016, nr 324 (82), s. $57-68$.

[27] Maciąg J., Jakość sieciowego produktu turystycznego - definiowanie, wymiary i cechy jakościowe, „Studia Ekonomiczne. Zeszyty Naukowe Uniwersytetu Ekonomicznego w Katowicach" 2015, nr 215, s. 40-56.

[28] Misztal A., Rola euroregionów w rozwoju inicjatyw klastrowych, „Zeszyty Naukowe Politechniki Śląskiej. Organizacja i Zarządzanie” 2017, nr 100, s. 303-315.

[29] Piotrowski M., Standardy zarządzania klastrem, PARP, Warszawa 2014.

[30] Pisarek M., Lechowska J., Znaczenie klastra Podkarpackie Smaki w rozwoju regionalnej turystyki kulinarnej, ,Studia Komitetu Przestrzennego Zagospodarowania Kraju Polskiej Akademii Nauk" 2015, tom CLXII, s. 224-242.

[31] Połomska-Jasienowska A., Transgraniczne klastry jako forma wspótdziałania gospodarczego na pograniczu, ,Studia Ekonomiczne. Zeszyty Naukowe Uniwersytetu Ekonomicznego w Katowicach" 2016, nr 255, s. 176-185. 
[32] Rapacz A., Rola klastrów w kształtowaniu struktury i jakości produktu turystycznego regionu, „Prace Naukowe Uniwersytetu Ekonomicznego we Wrocławiu” 2008, nr 29, s. 106-117.

[33] Roman M., Klastry jako forma współdziałania w działalności turystycznej, „Zarządzanie i Finanse" 2013, t. 11, nr 1, cz. 3, s. 309-320.

[34] Roman M., Wpływ klastrów turystycznych na innowacyjność gospodarki turystycznej, "Studia i Prace Wydziału Nauk Ekonomicznych i Zarządzania Uniwersytetu Szczecińskiego" 2017, nr 48/3, s. 45-59.

[35] Roman M., Zawadka J., Klaster okopski jako forma innowacyjnych działań w agroturystyce, [w:] Gospodarka polska po 20 latach transformacji, red. S. Pangsy-Kania, G. Szczodrowski, Wydawnictwo Instytutu Wiedzy i Innowacji, Warszawa 2009.

[36] Sala K., Clusters as a form of cooperation and innovation on the example of the Bieszczady Cross-Border Tourism Cluster, "The Malopolska School of Economics in Tarnow Research Papers Collection” 2016, Vol. 32, no. 4, s. 87-96.

[37] Sikora K., Klastry turystyczne szansą rozwoju mikroregionów, „Zarządzanie i Finanse” 2012, Vol. 10, nr 1, cz. 2, s. 55-66.

[38] Skała M., Szpara K., Rola klastrów w promocji i rozwoju turystyki na przyktadzie Innowacyjnego Klastra Zdrowie i Turystyka Uzdrowiska Perty Polski Wschodniej [w:] Rola organizacji pozarzadowych $w$ rozwoju i promocji turystyki, red. B. Sawicki, A. Nizioł, M. Obodyński, Wydawnictwo Uniwersytetu Rzeszowskiego, Rzeszów 2012.

[39] Skowronek E., Klaster jako forma wspótpracy w turystyce, „Europa Regionum” 2015, t. XXIV, s. 129-140.

[40] Słomińska-Okła M., Klastry determinanta innowacyjności regionów w Polsce i na Ukrainie [w:] Wschód i Zachód w wymiarze globalnym, red. M. Miłek, D. Wilk-Jakubowski, R. Brzoza, Wydawnictwo Stowarzyszenia Współpracy Polska-Wschód, Kielce 2012.

[41] Staszewska J., Klaster perspektywa dla przedsiębiorców na polskim rynku turystycznym, Difin, Warszawa 2009.

[42] Szwinta P., Możliwości rozwoju transgranicznych klastrów turystycznych $w$ Polsce, „Prace Naukowe Uniwersytetu Ekonomicznego we Wrocławiu” 2015, nr 392, s. 138-146.

[43] Zbroja Z., Szlak wodny Berlin-Szczecin-Battyk - szansa dla regionu transgranicznego, http://www.pomerania.org.pl/files/site/149__szlak_bszb.-1.pdf (dostęp: 12.08.2017 r.).

\section{CLUSTER TOURISM PRODUCT AS A STRATEGIC CHALLENGE WITHIN TOURISM CLUSTER MANAGEMENT}

The article focuses on the problem of cluster tourism product, contemporary perceived as a strategic challenge to managing tourism clusters in Poland. Its two parts in a synthetical way present the range of tourism cluster activity, as well as the essence and significance of cluster tourism product. Basing on the results of the literature review and desk research it has been proved that tourism clusters can be treated as an element of economic development processes on macro, meso and micro levels. Their activity allows the fulfilment of diverse needs and expectations of tourists, on the other hand, however, strengthens economic competitiveness. They create conditions conducive to micro, small and medium entities of tourism economy, the previous strategic potential of which was of small competitive value. They help overcome weaknesses of Polish tourism economy, connected to the quality of tourism services, accommodation, scattered tourism offer and the level of exploiting the potential of tourism sector. Moreover, they facilitate the development of sustainable 
knowledge-based economy and provision of economic, social, and territorial cohesion, representing a specific form of territorial partnership, regional and sectoral, and sometimes even interregional and intersectoral cooperation. Simultaneously, the article emphasizes that tourism cluster development requires efficient management and adequate support of key stakeholders, among others, public partners, investors. In order to optimally bring benefits (added value) for their internal and external stakeholders, on the territory where they are rooted, an adequately integrated cluster tourism product must be devised and subsequently flexibly offered to clients (tourists). Cooperation in the area of diversified cluster members, among others, representatives of business, $R \& D$, and business environment institutions, increases the chance for the success of this undertaking. The fundament of cluster tourism product consists in the combination of its quality and innovativeness, with specific traits of the region where a cluster is rooted, including its environmental advantages and multidimensional cultural and historical heritage.

Keywords: cluster, management, tourism, marketing, product, development.

DOI: 10.7862/rz.2017.mmr.23

Tekst złożono do redakcji: grudzień 2017 r.

Tekst przyjęto do druku: grudzień 2017 r. 
